\title{
Antifeeding and Insecticidal Activity of Ailanthus altissima and Morus alba Extracts Against Gipsy Moth (Lymantria dispar (L.), Lepidoptera, Lymantridae) Larvae Under Laboratory Conditions
}

\author{
Snežana TANASKOVIĆ 1 Sonja GVOZDENAC ${ }^{2}$ \\ Vojislava BURSIĆ ${ }^{4}$ Bojan KONSTANTINOVIĆ \\ Radenka KOLAROV ${ }^{3}$ \\ Dejan PRVULOVIĆ6*
}

\author{
${ }^{1}$ Faculty of Agronomy, University of Kragujevac, Cara Dušana 34, 32102 Čačak, SERBIA \\ ${ }^{2}$ Institute of Field and Vegetable Crops, Maksima Gorkog 30, 21000 Novi Sad, SERBIA \\ $3,4,5,6$ Faculty of Agriculture, University of Novi Sad, \\ trg Dositeja Obradovića 8, 21000 Novi Sad, SERBIA \\ e-mails: ${ }^{1}$ stanasko@kg.ac.rs, ${ }^{2}$ gvozdenacsonja@gmail.com, \\ ${ }^{3}$ kolar.rada@gmail.com, 4bursicv@polj.uns.ac.rs, ${ }^{5}$ bojank@polj.uns.ac.rs, \\ 6*dejanp@polj.uns.ac.rs \\ ORCID IDs: ${ }^{10000-0002-7853-2328, ~}{ }^{2} 0000-0001-9366-5172,{ }^{3} 0000-0003-1976-7618$, \\ ${ }^{4} 0000-0001-8331-095 X,{ }^{5} 0000-0001-5071-1386,{ }^{6} 0000-0002-1880-4934$
}

\begin{abstract}
Gypsy moth (Lymantria dispar (L.) is one of most important defoliating pests of deciduous trees. Due to increased environmental demands, the use of plant-based preparations is gaining in importance as a control option for this pest in forestry, agriculture and horticulture. The aim of this study was to evaluate antifeeding and insecticidal activity of $0.5,1$ and $2 \%$ extracts of Ailanthus altissima bark and leaves, and Morus alba leaves, against $L$. dispar larvae under laboratory conditions. Antioxidant capacity of plant extracts was determined, as well as the content of phenolic compounds by spectrophotometric and HPLC-DAD methods. Antifeeding and insecticidal effects were tested in a "no-choice" test. The highest content of all bioactive phenolic compounds was in $A$. altissima bark and $M$. alba leaf extracts. The lowest leaf consumption after 24 and $48 \mathrm{~h}$ was in $A$. altissima bark $(5.03,9.30 \%$, respectively) and $M$. alba leaf $(1.44,3.22 \%$, respectively) extracts. A. altissima bark and $M$. alba leaf extracts expressed strong antifeeding activity. After $24 \mathrm{~h}$, all extracts expressed slight insecticidal effect $(2.25-17.50 \%$ of mortality). The mortality increased after $48 \mathrm{~h}$ in treatments with $A$. altissima bark extract, at all applied concentrations $(40.0-57.50 \%)$ and $M$. alba leaves at 1 and $2 \%$ concentrations (30.0-62.50\%). Our results indicate that extracts of $A$. altissima bark and $M$. alba leaves may act as effective low-cost natural protectants able to control the presence of gypsy moth in ecosystems. Extracts of $A$. altissima bark and $M$. alba leaves expressed strong antifeeding activity and significant insecticidal effect on gypsy moth larvae, at all applied concentrations.
\end{abstract}

Key words: Lymantria dispar (L.), botanical insecticides, feeding intensity, larval mortality, phenolic compounds.

Tanasković, S., Gvozdenac, S., Kolarov, R., Bursić, V., Konstantinović, B., \& Prvulović, D. (2021). Antifeeding and insecticidal activity of Ailanthus altissima and Morus alba extracts against gipsy moth (Lymantria dispar [L.], Lepidoptera, Lymantridae) larvae under laboratory conditions. Journal of the Entomological Research Society, 23(3), 197-212. 


\section{INTRODUCTION}

Gypsy moth (Lymantria dispar (L.), Lepidoptera; Lymantridae) is one of the most devastating defoliating pests of deciduous forests, but it is also very harmful in orchards and urban greenery (Kostić, Popović, Brkić \& Milanović, 2008; Milanović et al, 2014; Cao et al, 2015). To prevent losses that gypsy moth larvae cause in forestry, agriculture and horticulture, it is necessary to harmonize pest control strategies with the principles of integrated pest management, using selective and less toxic insecticides, mechanical measures and biological insecticides (Bacillus thuringiensis var. kurstaki or botanical insecticides like azadirachtin) (Kostić et al, 2008; Singh, Cheema \& Singh, 2020). Koul (2005) reported growing interest in use of botanical preparations (i.e. plant-based insecticides) for the control of gypsy moth in organic and sustainable agriculture due to increased environmental demands. Botanical insecticides based on secondary plant metabolites represent an important group of biopesticides (Drobnjaković et al, 2018).

Plants are a rich source of compounds that exhibit high biological activity against harmful insects, thus botanical preparations are good potential substitutes for synthetic insecticides in agricultural and forest pest control (Bohinc et al., 2020; Šućur et al, 2015; Hikal, Baeshen \& Said-Al Ahl, 2017; Gvozdenac, Šućur, Manojlović, Prvulović \& Malenčić, 2018). In recent years, antifeeding effects of various plants and plant extracts have been studied for gypsy moth larvae and several findings confirm the antifeedant or repellent activity of Pinus taeda L., Juniperus virginiana L., Acer rubrum L. (Keena \& Richards, 2020), Ocimum basilicum L. (Kostić et al, 2008; Popović et al, 2013), Morus alba L. and Aesculus hippocastanum L. (Gvozdenac, Inđić, Vuković, Grahovac \& Tanasković, 2012). Botanical insecticides have many advantages, primarily low toxicity and selectivity towards non-target, and high toxicity to target organisms and also the capacity to avoid the occurrence of insect resistance and biodegradability (Kostić et al, 2008; Krinski, Massaroli \& Machado, 2014).

Ailanthus altissima (Mill.) Swingle, commonly known as the "tree of heaven", is a perennial invasive species, native to China and introduced in Europe at the end of $18^{\text {th }}$ century (Kowarik \& Säumel, 2007; De Feo, Mancini, Voto, Curini \& Digilio, 2009). The extracts and essential oils obtained from different parts of $A$. altissima have been reported to exhibit diverse biological activities, such as antioxidant (Aissani, Jabri, Mabrouk \& Sebai, 2018), phytotoxic (Albouchi, Hassen, Casabianca \& Hosni, 2013; Caser et al, 2020; Kozuharova, Benbassat, Berkov \& lonkova, 2020), antimicrobial (Albouchi et al, 2013; Aissani et al, 2018; Kozuharova et al, 2020), insecticidal (De Feo, Mancini, Voto, Curini \& Digilio, 2009; Pavela, Zabka, Tylova \& Kresinova, 2014), and also different pharmacological effects (Rahman, Rasool \& Imran, 2019). Morus alba L., white mulberry, is native to eastern and central China, India and Japan (Kostić et al, 2013). The leaves of $M$. alba are the main source of food for silkworm, thus white mulberry is cultivated throughout the world, wherever silkworms are or were reared. In European countries it is grown also for fruit production (Sanghi \& Mushtaq, 2017). The leaves of $M$. alba are traditionally used in Asian countries as a treatment for coughs, fever, sore and inflamed eyes, sore throats, headaches, dizziness and vertigo. Modern medicine proves the antidiabetic, antioxidant, anticancer, antimicrobial, 
Antifeeding and Insecticidal Activity of Ailanthus altissima and Morus alba

hepatoprotective and neuroprotective activity of $M$. alba extracts (Singh et al, 2013; Sanghi \& Mushtaq, 2017; Thaipitakwong, Numhom \& Aramwit, 2018). However, the reports on potential use of white mulberry extracts in pest management are scarce.

The aim of this study was to evaluate biological activity and assess effects of aqueous extracts of $A$. altissima leaves and bark, and $M$. alba leaves on feeding intensity (antifeeding activity) and mortality of gypsy moth larvae in laboratory conditions.

\section{MATERIAL AND METHODS}

\section{Plant extracts}

For bioassay, extracts of Ailanthus altissima (Mill.) Swingle bark and leaves, and Morus alba L. leaves were used. Plant material was collected on Suvobor (44.1339 $\left.\mathrm{N}, 20.2195^{\circ} \mathrm{E}\right)$ and Jeljen $\left(44.0007^{\circ} \mathrm{N}, 20.2589^{\circ} \mathrm{E}\right)$ mountain (Serbia). The plant species was identified by a botanist, and a voucher specimen has been deposited in the Herbarium (labelled as A. altissima - 17708 and M. alba - 17709) of Botanical Garden, Belgrade, Serbia.

Plant parts were previously dried at dark and windy place, at $20^{\circ} \mathrm{C}$. Plant material $(10.0 \mathrm{~g})$ was extracted with $70 \%$ ethanol $(100.0 \mathrm{~mL})$ as a solvent. The extraction was carried out using ultrasonic bath at room temperature for $1 \mathrm{~h}$. Extracts were diluted in distilled water to concentrations of $0.5,1$ and $2 \%$, and applied to oak leaf slices $(30 \times 30 \mathrm{~mm})$ by soaking method for $5 \mathrm{sec}$. Leaf slices soaked in distilled water were untreated control. Leaves were air-dried for $20 \mathrm{sec}$ after the extract application.

\section{Chemical analysis of plant extracts}

\section{Total phenolic, total tannin and antioxidant capacity}

Components of non-enzyme antioxidative system were determined using spectrophotometric methods with UV/VIS spectrophotometer (model Evolution 220, Thermo Fisher Scientific, USA).

Total phenol content (TP) was determined by colorimetric method using Folin-Ciocalteu reagent (Saha et al, 2013). Total tannin content (TT) was determined by the Folin-Ciocalteu procedure, after removal of tannins by their adsorption on insoluble matrix PVPP (polyvinylpolypyrrolidone). Calculated values were subtracted from total phenols content. Results were expressed as micrograms of quercetin equivalents per $1 \mathrm{~mL}$ of plant extracts ( $\mu \mathrm{g} \mathrm{QE} / \mathrm{mL})$.

Free radicals scavenging activity was tested in a DPPH (2,2-diphenyl-1-picrylhydrazyl) acetone solution (Lai \& Lim, 2011). Ferric reducing antioxidant power (FRAP) assay was performed according to the method of Valeñtao et al (2002). The scavenging activity of the plant extracts on $\mathrm{ABTS}^{+}$radical (2,2-Azino-bis (3-ethylbenzothiazoline6-sulfonic acid)) was measured according to the method of Re et al (1999). The total antioxidant activity (TAA) of plant extracts were evaluated by phosphomolybdenum method as reported by Kalaskar \& Surana (2014). The standard curve for antioxidant 
capacity (activity) was plotted using ascorbic acid (AsA) solution. Superoxide dismutase (SOD) mimetic_activity was assayed according to the method of Mandal, Mitra \& Mallick (2008) slightly modified by measuring ability of plant extracts to inhibit photochemical reduction of nitro blue tetrazolium (NBT) chloride. One unit of the SOD mimetic activity was defined as the amount of enzymes required to inhibit reduction of NBT by $50 \%$. The activity was expressed as IU per $1 \mathrm{~mL}$ of plant extracts.

\section{HPLC-DAD analysis of phenolic compounds}

All solvents used were of chromatography grade and obtained from J.T. Baker (Deventer, Netherlands). The analytical standards (manufactured by Sigma-Aldrich) used in the research are: trans-cinnamic acid (99.0\%), 2-hydroxy cinnamic acid $(97.0 \%)$, caffeic acid $(98.0 \%)$, p-coumaric acid $(98.0 \%)$, chlorogenic acid $(95.0 \%)$, quercetin $(98.0 \%)$, and kaempferol $(97.0 \%)$. The stock standard solutions were prepared by dissolving an analytical standard in methanol while the working solution i.e. the mixture of the studied phenol compounds was obtained by mixing and diluting the stock standards with mobile phase resulting in the final mass concentration of 100 $\mu \mathrm{g} / \mathrm{mL}$. The composite mixtures of all phenol compounds at appropriate concentrations were used to spike samples in validation data settings. Acetic acid was of "pure for analysis" grade (J.T. Baker, Deventer, Netherlands).

The chromatographic separation of phenolic compounds was achieved using the Agilent 1100 (Agilent Technologies, USA) HPLC system with a binary pump and diode array detector - DAD. The phenolic acids were separated on a ZORBAX SB-Aq (5 $\mu \mathrm{m}$ particle size: $4.6 \times 250 \mathrm{~mm}$, Agilent) column. The extracts were filtered through $0.45 \mu \mathrm{m}$ syringe filters and directly injected through a $30 \mu$ fixed loop into the column. The mobile phase was acetonitrile with $2.0 \%$ acetic acid (solvent $A$ ) and Milli- $Q$ water with $2.0 \%$ acetic acid (solvent $B$ ) in gradient mode, with the flow rate of $1.0 \mathrm{~mL} / \mathrm{min}$, equipped with a ZORBAX SB-Aq column. The gradient was as follows: $92 \% \mathrm{~A}$ at 0 $\mathrm{min}, 80 \% \mathrm{~A}$ at $18 \mathrm{~min}, 60 \% \mathrm{~A}$ at $25 \mathrm{~min}, 55 \% \mathrm{~A}$ at $30 \mathrm{~min}, 35 \% \mathrm{~A}$ at $40 \mathrm{~min}$ and $20 \%$ A at $42 \mathrm{~min}$. Stop time was $2.5 \mathrm{~min}$.

The detector linearity response was checked by preparing the blank plant extract sample (bark and leaves separately) and after the extraction the residue was diluted in $1.5 \mathrm{~mL}$ of the phenol compounds mixture standard in mass concentrations of 10.0 , 25.0, 50.0 and $100.0 \mu \mathrm{g} / \mathrm{mL}$.

The extracts were filtered through $0.45 \mu \mathrm{m}$ syringe filters and directly injected into the HPLC-DAD. The repeatability of the method was determined by analyzing the sample of the same mass concentration level $(10.0 \mu \mathrm{g} / \mathrm{mL})$ in six replicates and shown as the relative standard deviation - RSD (\%). The detection limit (LOD) was defined as the amount of phenolic compounds which produces the signal three times the noise signal. The quantification limit (LOQ) is the amount of phenolic compounds produces a signal ten times the noise signal. The LODs were determined by adding $100 \mu \mathrm{L}$ of phenols mixture standard to the concentration of $1.0 \mu \mathrm{g} / \mathrm{mL}$, in $0.5 \mathrm{~g}$ of the sample in six replicates and the LOQs was calculated. 
Antifeeding and Insecticidal Activity of Ailanthus altissima and Morus alba

\section{Bioassay}

\section{Insects collecting and rearing}

Egg masses of gypsy moth field population were collected from oak trees (Apatin, northern Serbia) during the winter $2018 / 19$ and kept in a refrigerator $\left(3^{\circ} \mathrm{C}\right)$ until the beginning of the experiment. Eggs were separated from mass and placed in glass tubes $(\varnothing 1 \mathrm{~cm}$, height $16 \mathrm{~cm})$, previously filled with water up to $1 / 4$ of volume, on a layer of cotton wool (which does not have the contact with water). Tubes were closed with cotton wool cover to prevent the larvae from leaving the tube after hatching. Tubes with eggs were incubated at $22-25^{\circ} \mathrm{C}$ and a normal light regime for 3-5 days. After hatching, $L_{1}$ larvae were isolated from the tubes with a soft brush, placed in Petri dishes and fed daily with fresh Quercus robur leaves, until the stage $L_{2} / L_{3}$.

\section{Feeding intensity and insecticidal effects}

Feeding intensity of extracts was assessed in a "no-choice" test. Ten larvae $\left(\mathrm{L}_{2} /\right.$ $\mathrm{L}_{3}$ ratio 1:1) per replication were introduced in Petri dishes $(\varnothing 14)$ containing two oak leaf slices $(30 \times 30 \mathrm{~mm})$ previously treated with an extract, or distilled water in the control variant. "No choice" test was carried out at room temperature $\left(22-25^{\circ} \mathrm{C}\right)$ and usual light regime (16:8). Feeding intensity, expressed as consumed leaf area $\left(\mathrm{mm}^{2}\right)$, was measured after 24 and $48 \mathrm{~h}$ and for further analysis the obtained values were transformed in relative values (\%).

Antifeeding activity of extracts was assessed using Antifeeding index (AFI) and calculated according to Farrar, Barbour \& Kennedy (1989):

$$
A F I=(C-T / C+T) \times 100
$$

C- Consumed area in the control variant (\%); T- consumed area in the treatment (\%)

The criterion according to Liu, Goh \& Ho (2007), was applied to categorize the plants:

$$
\begin{aligned}
& \text { AFI }<20 \% \text { - no antifeeding activity (-) } \\
& 50 \%>\mathrm{AFI} \geq 20 \% \text { - slightly antifeeding activity }(+) \\
& 70 \%>\mathrm{AFI} \geq 50 \% \text { - medium antifeeding activity }(++) \\
& \mathrm{AFI} \geq 70 \% \text { - strong antifeeding activity (+++) }
\end{aligned}
$$

Insecticidal effect was also assessed in the "No-choice" test. Dead and paralyzed larvae (determined by "palpation method") were counted after 24 and $48 \mathrm{~h}$ and the values were transformed into $\%$.

All experiments were set up in four replications.

\section{Statistical analysis}

The data on the consumed leaf area (\%) were subjected to Two-way analysis of variance (ANOVA) to evaluate the influence of two factors and their interaction. The first factor was the plant species and the second was the concentration of extracts. Duncan's multiple range test was used to assess the significance of differences 
between treatments, only for the factor that had significant influence on feeding intensity and mortality. All tests were performed at the level of significance $95 \%$ in software STATISTICA.10.

\section{RESULTS}

\section{Chemical composition of plant extracts}

Spectrophotometric methods are widely used for a rapid determination of different phe-nolic compounds and antioxidant capacity of plant samples. The content of extracted phenolic and antioxidant compounds differed on the plant species and selected plant part (Table 1). The yield of total phenols in extracts, expressed as quercetin equivalents (QE), varied between 2.74 (M. alba leaves extract) and 163.25 (A. altisima bark extract) $\mathrm{mg} / \mathrm{g}$ of dry plant material. The content of total tannins and antioxidant capacity of extracts of selected plants, measured by five different assays, followed the same pattern as the total phenolic content.

Table 1. Phenolic content and antioxidant capacity of $A$. altissima and $M$. alba extracts.

\begin{tabular}{|l|c|c|c|c|}
\hline \multicolumn{1}{|c|}{ Parameter } & \multicolumn{3}{|c|}{ Extract } & F value \\
\hline & A. altissima bark & A. altissima leaves & M. alba leaves & \\
\hline TP (mg QE/g) & $163.25 \pm 3.42 \mathrm{a}$ & $17.90 \pm 0.55 \mathrm{~b}$ & $2.74 \pm 0.07 \mathrm{~d}$ & $8324.07^{* *}$ \\
\hline TT (mg QE/g) & $141.51 \pm 1.73 \mathrm{a}$ & $14.93 \pm 0.15 \mathrm{~b}$ & $1.96 \pm 0.03 \mathrm{~d}$ & $18931.69^{* *}$ \\
\hline DPPH (mg AsA/g) & $41.07 \pm 1.66 \mathrm{a}$ & $3.76 \pm 0.09 \mathrm{~b}$ & $0.19 \pm 0.02 \mathrm{~d}$ & $7495.9^{* *}$ \\
\hline FRAP (mg AsA/g) & $15.79 \pm 2.37 \mathrm{a}$ & $5.27 \pm 0.36 \mathrm{~b}$ & $0.19 \pm 0.01 \mathrm{c}$ & $295.6^{* *}$ \\
\hline ABTS (mg AsA/g) & $84.52 \pm 7.47 \mathrm{a}$ & $13.19 \pm 1.26 \mathrm{~b}$ & $1.21 \pm 0.05 \mathrm{c}$ & $354.70^{* *}$ \\
\hline TAA (mg AsA/g) & $16.67 \pm 1.47 \mathrm{a}$ & $2.64 \pm 0.11 \mathrm{~b}$ & $0.29 \pm 0.02 \mathrm{~d}$ & $340.49^{* *}$ \\
\hline SOD mimetic (IU/g) & $1324.27 \pm 126 \mathrm{a}$ & $365.55 \pm 32.2 \mathrm{~b}$ & $38.10 \pm 3.73 \mathrm{~d}$ & $469.49^{* *}$ \\
\hline
\end{tabular}

DPPH - 2,2-diphenyl-1-picrylhydrazyl; FRAP - Ferric reducing antioxidant power; ABTS - 2,2-Azino-bis

(3-ethylbenzothiazoline-6-sulfonic acid); TAA - total antioxidant activity; SOD - superoxid dismutase;

AsA - ascorbic acid; TP - total phenolics; TT - total tannins; QE- quercetin equivalents

The method for HPLC-DAD analysis of phenolic compounds was evaluated in terms of linearity and repeatability, LOD and LOQ for trans-cinnamic, 2-hydroxy cinnamic, caffeic, p-coumaric and chlorogenic acid, quercetin and kaempferol. The obtained LODs for all investigated phenolic compounds were $0.01 \mu \mathrm{g} / \mathrm{mL}$ with the LOQs of $0.03 \mu \mathrm{g} / \mathrm{mL}$. The HPLC analysis detected the presence of phenolic compounds in $A$. altissima bark, leaves and $M$. alba leaves (Table 2).

The dominant compound in $A$. altissima bark extract was kaempferol $(450.14 \mu \mathrm{g} / \mathrm{g})$ and 2 hidroxycinnamic acid $(434.49 \mu \mathrm{g} / \mathrm{g})$ and dominant compound in $A$. altissima leaf extract was also kaempferol followed by quercetin and 2 hidroxycinnamic acid. The most prevailing compound in $M$. alba leaves extract was kaempferol, followed by 2 hydroxycinnamic acid, quercetin and caffeic acid. 
Antifeeding and Insecticidal Activity of Ailanthus altissima and Morus alba

Table 2. HPLC-DAD detected and quantified phenolic compounds in A. altissima and M. alba extracts.

\begin{tabular}{|l|c|c|c|}
\hline \multirow{2}{*}{ Phenolic compounds $(\mu \mathrm{g} / \mathrm{g})$} & \multicolumn{3}{|c|}{ Extract } \\
\cline { 2 - 4 } & A.altisima bark & A.altisima leaves & M.alba leaves \\
\hline caffeic acid (hydro cinnamic) & 55.91 & $<\mathrm{OQQ}$ & 6.8 \\
\hline trans cinnamic acid & 35.94 & $<\mathrm{OOQ}$ & $<\mathrm{LOQ}$ \\
\hline 2 hidroxycinnamic acid & 434.49 & 3.96 & 12.84 \\
\hline chlorogenic acid & 71.83 & $<\mathrm{LOQ}$ & $<\mathrm{LOQ}$ \\
\hline p-coumaric acid & 42.16 & $<\mathrm{LOQ}$ & $<\mathrm{LOQ}$ \\
\hline Kaempferol & 450.14 & 19.22 & 32.0 \\
\hline Quercetin & 8.86 & 5.96 & 6.95 \\
\hline
\end{tabular}

LOQ - Limit of quantification.

\section{Bioassay}

\section{Feeding intensity of gypsy moth larvae}

Two-way ANOVA results indicate that after $24 \mathrm{~h}$ only plant species, and the interaction of plant species $x$ concentration, had statistically significant influence on the feeding intensity (consumed leaf area) of gypsy moth larvae (Table 3 ). However, after $48 \mathrm{~h}$, both factors and their interaction had significant influence of the feeding intensity of gypsy moth larvae.

Table 3. The influence of different factors and their interaction on feeding intensity of gypsy moth larvae.

\begin{tabular}{|l|c|c|c|c|}
\hline Factors (sources of variation) & SS & DF & MS & F value \\
\hline $24 \mathrm{~h}$ & & & & \\
\hline extract & 136345.5 & 5 & 27269.1 & $2005.05^{\prime \prime}$ \\
\hline concentration & 38.5 & 2 & 19.2 & $1.41 \mathrm{~ns}$ \\
\hline extract x concentration & 468.9 & 10 & 46.9 & $3.45^{* \prime}$ \\
\hline $48 \mathrm{~h}$ & & & & \\
\hline extract & 145626.0 & 5 & 29125.2 & $4207.09^{* \prime}$ \\
\hline concentration & 76.9 & 2 & 38.4 & $5.55^{*}$ \\
\hline extract x concentration & 394.3 & 10 & 39.4 & $5.70^{* \prime}$ \\
\hline
\end{tabular}

ns - non significant differences ( $p>0.05),{ }^{*}$ - significant differences $(p<0.05) ;{ }^{* *}$ - highly significant differences $(p<0.01)$; SS-sum of squares; df-degrees of freedom; MS-median

Feeding intensity of gypsy moth larvae was assessed based on the average value of consumed leaf area (\%) (Table 4). After $24 \mathrm{~h}$ the lowest average feeding intensity was registered in treatments with extracts of $M$. alba leaves $(1.44 \%)$ and $A$. altissima bark $(5.03 \%)$. The increase of concentration significantly reduced the feeding intensity 
in treatments with $A$. altissima bark. The difference between the average consumed leaf area was highly significant $\left(F=21604.43^{* *}, p<0.05\right)$. After $48 \mathrm{~h}$, the lowest feeding intensity was in treatments with $M$. alba leaves (3.22\%) and $A$. altissima bark $(9.30 \%)$ and it was concentration-dependant, namely the feeding intensity decreased with the increase of concentration. The differences between consumed leaf area are highly significant $\left(F=76689.33^{* *}, p<0.01\right)$.

Table 4. Feeding intensity of gypsy moth larvae.

\begin{tabular}{|c|c|c|c|c|c|}
\hline \multirow{2}{*}{ Extract } & \multicolumn{3}{|c|}{$\%$ of consumed leaf area } & \multirow{2}{*}{ Average (\%) } & \multirow{2}{*}{ F value } \\
\hline & $0.5 \%$ & $1 \%$ & $2 \%$ & & \\
\hline \multicolumn{6}{|c|}{$24 \mathrm{~h}$} \\
\hline A. altissima (bark) & $6.72 \pm 0.81 \mathrm{aB}$ & $5.12 \pm 1.03 \mathrm{aB}$ & $3.06 \pm 0.44 \mathrm{bB}$ & $5.03 \mathrm{c}$ & $4.25^{*}$ \\
\hline A. altissima (leaves) & $91.31 \pm 2.11 \mathrm{aA}$ & $90.22 \pm 1.22 \mathrm{aA}$ & $89.10 \pm 2.17 \mathrm{aA}$ & $90.21 \mathrm{a}$ & $2.19 \mathrm{~ns}$ \\
\hline M. alba (leaves) & $2.04 \pm 0.15 \mathrm{aC}$ & $1.07 \pm 0.11 \mathrm{aC}$ & $1.20 \pm 0.09 \mathrm{aB}$ & $1.44 \mathrm{~d}$ & $4.33 \mathrm{~ns}$ \\
\hline Control & $90.33 \pm 2.41 \mathrm{aA}$ & $90.47 \pm 1.22 \mathrm{aA}$ & $82.11 \pm 3.65 \mathrm{aA}$ & $87.64 b$ & $0.85 \mathrm{~ns}$ \\
\hline$F$ value & $28253.89^{* *}$ & $27622.35^{* *}$ & $28824.55^{* *}$ & $21604.43^{* *}$ & \\
\hline \multicolumn{6}{|c|}{$48 \mathrm{~h}$} \\
\hline A. altissima (bark) & $11.97 \pm 4.23 \mathrm{aB}$ & $11.27 \pm 1.3 \mathrm{aB}$ & $4.67 \pm 2.02 \mathrm{bB}$ & $9.30 \mathrm{~b}$ & $621.97^{* *}$ \\
\hline A. altissima (leaves) & $96.92 \pm 0.67 \mathrm{aA}$ & $98.51 \pm 2.15 \mathrm{aA}$ & $95.87 \pm 2.11 \mathrm{aA}$ & $97.10 \mathrm{a}$ & $4.11 \mathrm{~ns}$ \\
\hline M. alba (leaves) & $6.55 \pm 0.11 \mathrm{aC}$ & $1.52 \pm 0.16 b C$ & $1.12 \pm 0.11 \mathrm{bC}$ & $3.22 \mathrm{c}$ & $47.60^{* *}$ \\
\hline Control & $97.55 \pm 1.34 \mathrm{aA}$ & $97.40 \pm 1.75 \mathrm{aA}$ & $97.11 \pm 0.63 \mathrm{aA}$ & $97.35 \mathrm{a}$ & $1.33 \mathrm{~ns}$ \\
\hline $\mathrm{F}$ value & $79379.91^{* *}$ & $28824.96^{* *}$ & $96485.43^{* *}$ & $76689.33^{* *}$ & \\
\hline
\end{tabular}

Values with the same lowercase letters are at the same level of significance in columns- between concentrations $(\alpha=0.05)$; Values with the same uppercase letters are at the same level of significance in rows- between plant species ( $\alpha=0.05)$; ns - non significant differences $(p>0.05),{ }^{*}$ - significant differences $(p<0.05) ;{ }^{* *}$ - highly significant differences $(p<0.01)$.

Based on antifeeding activity index (AFI values), after 24 and $48 \mathrm{~h}$, the extracts of $A$. altissima bark and $M$. alba leaves expressed strong antifeeding activity on gypsy moth larvae regardless on the concentration (Table 5). However, the extracts of $A$. altissima leaves did not cause antifeeding effect regardless on the applied concentration (AFI ranged from 0.20 to 3.55 after $24 \mathrm{~h}$ and 0.32 to 0.87 after $48 \mathrm{~h}$ ).

The mortality of gypsy moth larvae increased after $48 \mathrm{~h}$ in treatments with $A$. altissima bark and leaf extracts, at all applied concentrations (40.0 - 57.50\%) as presented in Table 6.

\section{CONCLUSIONS AND DISCUSSION}

The content of phenolic compounds in $M$. alba leaf extracts is greatly influenced by a growing region (Radojković, Zeković, Vidović, Kočar \& Mašković, 2012; Kim 
Antifeeding and Insecticidal Activity of Ailanthus altissima and Morus alba

et al, 2014; Polumackanycz, Sledzinski, Goyke, Wesolowski \& Viapiana, 2019), cultivar (Lee \& Choi, 2012; Sánchez-Salcedo, Mena, García-Viguera, Hernández \& Martínez, 2015; Pothinuch \& Tongchitpakdee, 2019), harvest period (Lee \& Choi, 2012; Pothinuch \& Tongchitpakdee, 2019), heat processing (Lee \& Choi, 2012), extraction solvent (Polumackanycz et al, 2019), and processing conditions (Przeor et al, 2020).

Table 5. Antifeeding activity of tested plant extracts on gypsy moth larvae.

\begin{tabular}{|l|c|c|c|c|}
\hline \multirow{2}{*}{ Extracts } & \multicolumn{4}{|c|}{ Antifeeding activity } \\
\cline { 2 - 5 } & \multicolumn{2}{|c|}{$24 \mathrm{~h}$} & \multicolumn{2}{|c|}{$48 \mathrm{~h}$} \\
\cline { 2 - 5 } & AFI & activity & AFI & activity \\
\hline A. altissima (bark) 0.5\% & 91.34 & +++ & 77.43 & +++ \\
\hline A. altissima (bark) 1\% & 95.05 & +++ & 87.50 & +++ \\
\hline A. altissima (bark) 2\% & 93.52 & +++ & 79.33 & +++ \\
\hline A.altissima (leaves) 0.5\% & 3.55 & - & 0.32 & - \\
\hline A. altissima (leaves) 1\% & 2.32 & - & 0.36 & - \\
\hline A. altissima (leaves) $\%$ & 0.20 & - & 0.87 & - \\
\hline M. alba (leaves) 0.5\% & 85.54 & +++ & 92.08 & +++ \\
\hline M. alba (leaves) 1\% & 89.11 & +++ & 95.15 & +++ \\
\hline M. alba (leaves) 2\% & 96.44 & +++ & 93.43 & +++ \\
\hline
\end{tabular}

- no antifeeding activity; +++ - strong antifeeding activity.

Table 6. Mortality (\%) of gypsy moth larvae in treatments with A. altissima and M. alba extracts.

\begin{tabular}{|c|c|c|c|c|}
\hline \multirow{2}{*}{ Extracts } & \multicolumn{4}{|c|}{ Mortality (\%) } \\
\hline & $24 \mathrm{~h}$ & $\mathrm{~F}$ value & $48 \mathrm{~h}$ & $\mathrm{~F}$ value \\
\hline A. altissima (bark) $0.5 \%$ & $13.50 \pm 0.50 a b$ & \multirow{3}{*}{$36.76^{* *}$} & $40.00 \pm 0.00 \mathrm{bc}$ & \multirow{3}{*}{$556.47^{\star *}$} \\
\hline A. altissima (bark) $1 \%$ & $10.00 \pm 1.00 b$ & & $43.33 \pm 0.51 b$ & \\
\hline A. altissima (bark) $2 \%$ & $16.50 \pm 1.03 a$ & & $57.50 \pm 1.50 a$ & \\
\hline A. altissima (leaves) $0.5 \%$ & $2.25 \pm 0.25 d$ & \multirow{3}{*}{$83.31^{*}$} & $45.00 \pm 0.00 \mathrm{~b}$ & \multirow{3}{*}{$649.23^{* *}$} \\
\hline A. altissima (leaves) $1 \%$ & $3.75 \pm 0.20 \mathrm{~d}$ & & $30.00 \pm 1.00 \mathrm{c}$ & \\
\hline A. altissima (leaves) $2 \%$ & $4.77 \pm 0.17 \mathrm{~cd}$ & & $47.50 \pm 2.50 \mathrm{~b}$ & \\
\hline M. alba (leaves) $0.5 \%$ & $6.50 \pm 0.50 c$ & \multirow{3}{*}{$129.99^{* *}$} & $8.21 \pm 0.60 \mathrm{~d}$ & \multirow{3}{*}{$10107.71^{* *}$} \\
\hline M. alba (leaves) $1 \%$ & $10.00 \pm 1.00 b$ & & $30.00 \pm 0.40 c$ & \\
\hline M. alba (leaves) $2 \%$ & $17.50 \pm 0.25 a$ & & $62.50 \pm 0.50 a$ & \\
\hline Control & $2.50 \pm 0.10 \mathrm{~d}$ & I & $3.75 \pm 0.30 \mathrm{e}$ & l \\
\hline F value & $646.06^{* *}$ & I & $2324.11^{* *}$ & l \\
\hline
\end{tabular}

Values with the same lowercase letters are at the same level of significance in columns- between concentrations and plant species $(\alpha=0.05)$; ns - non significant differences $(p>0.05),{ }^{*}$ - significant differences $(p<0.05) ;{ }^{* *}$ - highly significant differences $(p<0.01)$ 
Various factors affect the content of phenolic compounds and antioxidant activity in A. altissima extracts: selected tissue or organ (Luis, Gil, Amaral, Domingues \& Duarte, 2012; Aissani et al, 2018), growing conditions (Vidović, Morina, Milić \& Veljović Jovanović, 2015), extraction solvent (Luis et al, 2012; Poljuha et al, 2017; Aissani et al, 2018), and processing conditions (Poljuha et al, 2017). According to several authors (Luis et al, 2012; Albouchi et al, 2013; Poljuha et al, 2017; Aissani et al, 2018) leaves and bark of $A$. altissima are rich sources of polyphenolic compounds and possess very strong antioxidant activity. Presented work is in agreement with the results obtained in our study that reveal that the bark extract possessed ten times higher content of total phenolics and total tannins compared to leaf extracts. Bark extract also manifested higher antioxidant capacity from three times (measured by FRAP assay) up to 11 times (measured by DPPH assay) comparing to $A$. altissima leaves extract.

Several authors reported that $M$. alba leaf extracts contain relatively high content of polyphenolic compounds and strong antioxidant activity (Kim et al., 2014; Polumackanycz et al, 2019; Lee \& Choi, 2012; Sánchez-Salcedo et al, 2015; Przeor et al, 2020). However, due to different extraction procedures and presentation of the results, it is hard to compare the results. Polumackanycz et al (2019) and Przeor et al (2020) obtained results similar to those reported in our study.

Several studies reveal more detailed chemical composition of $A$. altissima bark. Kowarik \& Säumel (2007) report that the bark contains oleoresin, resin, some mucilage, ceryl alcohol, ailanthon, 'quassiin', calcium oxalate crystals, and isoquercetin (quercitin 3-glycoside), tannin, phlobaphene, ceryl palmitate, saponin, quassin and neoquassin. Ailanthone was identified as the most effective phytotoxic component and may potentially be used as a broad spectrum herbicide (Lin et al, 1995; Heisey, 1996) and may potentially be used as a broad spectrum herbicide (Heisey \& Heisey, 2003). Besides ailanthone, which showed the greatest inhibitory activity, De Feo, Mancini, Voto, Curini \& Digilio (2009) isolated ailanthinone, chaparrine, and ailanthinol B (quassinoid derivatives), while Okunade et al (2003) isolated the quassinoids ailanthone and 6-alpha-tigloyloxychaparrinone and revealed antiplasmodial activity of these compounds and Tamura et al (2003) and Tamura, Fukamiya, Okano \& Koike (2006) detected new quassinoids: ailantinol E, F, G, and H. From the bark, Hwang et al (2005) isolated five coumarin derivatives.

Aissani et al (2018) identified quinic and syringic acids as dominant component in $A$. altissima leaf extract followed by caffeic and p-coumaric acids. The composition of $A$. altissima leaves differed from that of the bark. In bark extract, all tested phenolic acids (caffeic acid (hydro cinnamic, trans cinnamic acid, 2 hidroxycinnamic acid, chlorogenic acid, p-coumaric acid, kaempferol, quercetin) were detected in different amounts. The content of the majority of phenols investigated was many-fold lower in leaves (kaempferol, quercetin and 2 hydroxycinnamic acid), which is partially in accordance with the reports of other authors. In several studies (Luis et al, 2012; Albouchi et al, 2013; Vidović et al, 2015) quercetin was detected as one of the dominant phenolic compounds in extracts of $A$. altissima leaves, while our results point kaempherol and 2 hidroxycinnamic acid as the dominant components. 
Antifeeding and Insecticidal Activity of Ailanthus altissima and Morus alba

The obtained results for the most prevailing compound in $M$. alba leaves (kaempferol, followed by 2 hydroxycinnamic acid, quercetin and caffeic acid) are partially in agreement with previous findings. Flaczyk et al (2013) and Przeor et al (2020) detected chlorogenic and caffeic acids as a dominant components followed by p-coumaric acid, kaempferol and quercetin. Radojković et al (2012) identified ferulic acid, rutin, gallic acid and chlorogenic acid, among other compounds, in $M$. alba samples. Sánchez-Salcedo et al (2015) have reported quercetin derivatives, chlorogenic and caffeoylquinic acid as major components, but also kaempferol derivates.

Flavonoids, quercetin, chlorogenic acid and rutin are the most frequently found phenolic compounds among diverse crop species and represent a base of plants resistance (Rojht, Kosir \& Trdan, 2012; Martens, Preuss \& Matern, 2010; Hichri et al, 2011). They affect herbivore larval growth and development mainly by feeding inhibition (Treutter, 2006; Page, Sultana, Paszkiewicz, Florance \& Smirnoff, 2012). The results of our work is in compliance with these reports. The highest amount of all tested phenolic compounds including quercetin, chlorogenic acid and kaempferol detected by HPLC analysis was in the extract of $A$. altissima bark $(8.86,71.83$, and $450.14 \mu \mathrm{g} / \mathrm{g}$, respectively) which expressed the strongest antifeeding activity against gypsy moth larvae in this work. Onyilagha, Lazorko, Gruber, Soroka \& Erlandson (2004) also reported the detrimental effect of kaempferol from Brasica napus L. leaves to another lepidopterian pest, Mamestra configurata Walker. Beninger et al (2004) found that chlorogenic acid (100 and 1000 ppm) when added in artificial diet significantly reduced growth of $L$. dispar and Trichloplusia ni (Hübner) larvae, and according to Simmonds \& Stevenson (2001) and Simmonds (2003), the same effects were caused to Helicoverpa armigera (Hübner) (50 ppm).

The extract of $M$. alba leaves exhibited strong antifeeding effect, which is in accordance with the results of previous research of Gvozdenac et al (2012). Antifeeding activity can be attributed to kaemferol, 2 hidroxycinnamic and caffeic acid and quercetin detected in the extract. Stamp, Temple, Traugott \& Wilkens (1994) proved negative effects of caffeic acid on early stages of Manduca sexta (L.), which was also detected as the dominant phenolic compound in leaf extract of $M$. alba. Additionally, according to Pelletier (1996) over 250 different glycosides can be isolated from the leaves of $M$. alba, which are most probably responsible for feeding inhibition.

Previous studies prove that secondary metabolites released from roots and leaves of $A$. altissima have pronounced insecticidal effect (Heisey, 1996; Tsao, Romanchuk, Peterson \& Coats 2002), which is in accordance with the results obtained in this study. According to De Feo et al (2009), extract isolated from A. altissima plant was successfully used to control Acyrtosiphon pisum (Harris). Pavela (2011) reported insecticidal effects and anteefidant activity (FDI $41.6 \%$ ) of $A$. altissima leaf fractions on $4^{\text {th }}$ instar Leptinotarsa decemlineta (Say) larvae and acute and chronic toxicity, antifeedant efficacy and larval growth inhibition of leaf extract on Spodoptera littoralis (Bois.) (Pavela et al 2014). A. altissima leaf extract expressed oviposition deterrence of Spodoptera frugiperda (Smith) in a concentration-dependent manner, as reported 
by Wagner \& Card (2020). In this work, A. altissima bark extract expressed stronger insecticidal activity, compared to leaf extract. This is in compliance with reports of Lu \& Wu (2010) who tested essential oil of $A$. altissima bark but on different insect pests. The essential oil exhibited strong contact toxicity to Sitophilus oryzae (L.) adults (76.5\% mortality after $72 \mathrm{~h}$ of exposure), fumigant activity (99,3\% and $81.9 \%$ mortality within $24 \mathrm{~h}$ ) for Oryzaephilus surinamensis (L.) and S. oryzae respectively, and repellency (class IV) for adults of Tribolium castaneum (Herbst), O. surinamensis, S. oryzae and Liposcelis paeta (Pearman \& J.V.). However, there is no available research data on insecticidal effects of $A$. altissima bark extracts on lepidopteran larvae. Therefore, this work presents the first report on the bioactivity of $A$. altissima bark extract on gypsy moth larvae, emphasizing its high potential as a moth control agent. Extract of $M$. alba leaves expressed significant insecticidal effect at 1 and $2 \%$ concentrations (30.0 - 62.50\% mortality). These results comply with the reports from laboratory feeding tests of $L$. dispar larvae performed by Miller \& Hanson (1994). The authors suggested that plants from the genus Morus were unsuitable for larval development and even indicated a high mortality of younger larvae and reduced feeding intensity by fifth instars' caterpillars. Also, as mentioned, $M$. alba leaves contain nine glycoside compounds belong to the group of deoxynojirimycin which expressed inhibitory effect on phytophagous (Lepidoptera) larvae of Spodoptera frugiperda (Smith) (Pelletier, 1996).

Insect pests represent a growing economic and environmental problem worldwide. Due to their high availability and low toxicity, plant extracts may represent excellent repellents and insecticides to be used in different ecosystems. Our results indicate that extracts of $A$. altissima bark and leaves and $M$. alba leaves may act as an effective low-cost natural protectants able to control the presence of gypsy moth in ecosystems. Extracts of $M$. alba leaves and $A$. altissima bark at all applied concentrations expressed strong antifeeding activity and significant insecticidal effect on gypsy moth larvae.

\section{ACKNOWLEDGEMENTS}

This research was financially supported by the Ministry of Education, Science and Technological Development of the Republic of Serbia (grant numbers: 451-03-68/2020$14 / 200117$ and 451-03-68/2020-14/200032). The authors are thankful to the Dr Duško Brković, Department of Biology, Industrial Microbiology and Plant Protection, University of Kragujevac for the formal identification of the plant material used in study i.e. providing necessary vauchers for used plant material.

\section{REFERENCES}

Aissani, N., Jabri, M.-A., Mabrouk, M., \& Sebai, H. (2018). Antioxidant potential and antimicrobial activity of Ailanthus altissima (Mill.) Swingle extracts against Pseudomonas aeruginosa. Journal of Molecular Biology and Biotechnology, $3,3$.

Albouchi, F., Hassen, I., Casabianca, H., \& Hosni, K. (2013). Phytochemicals, antioxidant, antimicrobial and phytotoxic activities of Ailanthus altissima (Mill.) Swingle leaves. South African Journal of Botany, 87, 164-174. 
Antifeeding and Insecticidal Activity of Ailanthus altissima and Morus alba

Bohinc, T., Horvat, A., Ocvirk, M., Košir, I.J., Rutnik, K., \& Trdan S. (2020). The first evidence of the insecticidal potential of plant powders from invasive alien plants against rice weevil under laboratory conditions. Applied Sciences, 10(21), 7828.

Beninger, C.W., Abou-Zaid, M.M., Kistner, A.L., Hallett, R.H., Iqbal, M.J., Grodzinski, B., \& Hall, J.C. (2004). A flavanone and two phenolic acids from Chrysanthemum morifolium with phytotoxic and insect growth regulating activity. Journal of Chemical Ecology, 30, 589-606.

Cao, C., Sun, L., Wen, R., Shang, Q., Ma, L., \& Wang, Z. (2015). Characterization of the transcriptome of the Asian gypsy moth Lymantria dispar identifies numerous transcripts associated with insecticide resistance. Pesticide Biochemistry and Physiology, 119, 54-61.

Caser, M., Demasi, S., Caldera, F., Dhakar, N.K., Trotta, F., \& Scariot, V. (2020). Activity of Ailanthus altissima (Mill.) Swingle extract as a potential bioherbicide for sustainable weed management in horticulture. Agronomy, 10, 965.

De Feo, V., Mancini, E., Voto, E., Curini, M., \& Digilio, M.C. (2009). Bioassay-oriented isolation of an insecticide from Ailanthus altissima. Journal of Plant Interactions, 4, 119-123.

Drobnjaković, T., Marčić, D., Prijović, M., Perić, P., Milenković, S., \& Bošković, J. (2018). Sublethal effects of NeemAzal- T/S botanical insecticide on Dutch and Serbian populations of Encarsia formosa (Hymenoptera: Aphelinidae). Biocontrol Science and Technology, 28, 1-19.

Farrar, R.R. Jr., Barbour, J.D., \& Kennedy, G.G. (1989). Quantifying food consumption and growth in insects. Annals of the Entomological Society of America, 82(5), 593-598.

Flaczyk, E., Kobus-Cisowska, J., Przeor, M., Korczak, J., Remiszewski, M., Korbas, E., \& Buchowski, M. (2013). Chemical characterization and antioxidative properties of Polish variety of Morus alba L. Leaf aqueous extracts from the laboratory and pilot-scale processes. Agricultural Sciences, 4(5b), 141-147.

Gvozdenac, S., Inđić, D., Vuković, S., Grahovac, M., \& Tanasković, S. (2012). Antifeeding activity of several plant extracts against Lymantria dispar L. (Lepidoptera: Lymantridae) larvae. Pesticides and Phytomedicine, 27(4), 305-311.

Gvozdenac, S., Šućur, J., Manojlović, A., Prvulović, D., \& Malenčić, Đ. (2018). Influence of winter savory (Satureja montana) aqueous extract on mortality of lesser grain borer (Rhyzopertha dominica). Botanica Serbica, 42(2), 277-281.

Heisey, R.M. (1996). Identification of an allelopathic compound from Ailanthus altissima (Simaroubaceae) and characterization of its herbicidal activity. American Journal of Botany, 83(2), 192-200.

Heisey, R.M. \& Heisey, T.K. (2003). herbicidal effects under field conditions of Ailanthus altissima bark extract, which contains ailanthone. Plant and Soil, 256, 85-99.

Hichri, I., Barrieu, F., Bogs, J., Kappel, C., Delrot, S., \& Lauvergeat, V. (2011). Recent advances in the transcriptional regulation of the flavonoid biosynthetic pathway. Journal of Experimental Botany, 62(8), 2465-2483.

Hikal, W.M., Baeshen, R.S., \& Said-Al Ahl, H.A.H. (2017). Botanical insecticide as simple extractives for pest control. Cogent Biology, 3, 1404274.

Hwang, S.W., Lee, J.R., Lee, J., Kwon, H.S., Yang, M.S., \& Park, K.H. (2005). New coumarins from the Ailanthus altissima. Heterocycles, 65, 1963-1966.

Kalaskar, M.G. \& Surana, S.J. (2014). Free radical scavenging, immunomodulatory activity and chemical composition of Luffa acutangula var. Amara (Cucurbitaceae) pericarp. Journal of the Chilean Chemical Society, 59(1), 2299-2302.

Keena, M.A. \& Richards, J.Y. (2020). Comparision of survival and development of gypsy moth Lymantria dispar L. (Lepidoptera: Erebidae) population from different geographic areas on North American conifers. Insects, 11, 260.

Kim, D.-S., Kang, Y.M., Jin, W.Y., Sung, Y.-Y., Choi, G., \& Kim, H.K. (2014). Antioxidant activities and polyphenol content of Morus alba leaf extracts collected from varying regions. Biomedical Reports, 2(5), 675-680. 
Kostić, D.A., Dimitrijević, D.S., Mitić, S.S., Mitić, M.N., Stojanović, G.S., \& Zivanović, A.V. (2013). A survey on macro- and micro-elements, phenolic compounds, biological activity and use of Morus spp. (Moraceae). Fruits, 68, 333-347.

Kostić, M., Popović, Z., Brkić, D., \& Milanović. S. (2008). Larvicidal and antifeedant activity of some plant-derived compounds to Lymantria dispar L. (Lepidoptera, Lymantriidae). Bioresource Technology, 99(16), 7897-7901.

Koul, O. (2005). Insect antifeedants. CRC Press, Bota Racon, FL, USA.

Kowarik, I. \& Säumel, I. (2007). Biological flora of Central Europe: Ailanthus altissima (Mill.) Swingle. Perspectives in Plant Ecology, Evolution and Systematics, 8(4), 207-237.

Kozuharova, E., Benbassat, N., Berkov, S., \& lonkova, I. (2020). Ailanthus altissima and Amorpha fruticosa - invasive arboreal alien plants as cheap sources of valuable essential oils. Pharmacia, 67(2), 71-81.

Krinski, D., Massaroli, A., \& Machado, M. (2014). Potencial inseticida de plantas da família Annonaceae. Revista Brasileira de Fruticultura, 36, 225-242. https://doi.org/10.1590/S0100-29452014000500027.

Lai, H.Y. \& Lim, Y.Y. (2011). Evaluation of antioxidant activities of the methanolic extracts of selected ferns in Malaysia. International Journal of Environmental Science and Development, 2, 442-447.

Lee, W.J. \& Choi, S.W. (2012). Quantitative changes of polyphenolic compounds in mulberry (Morus alba L.) leaves in relation to varieties, harvest period, and heat processing. Preventive Nutrition and Food Science, 17(4), 280-285.

Lin, L.J., Peiser, G., Ying, B.P., Mathias, K., Karasina, F., Wang, Z., Itatani, J., Green, L., \& Hwang, Y.S. (1995). Identification of plant growth inhibitory principles in Ailanthus altissima and Castela tortuosa. Journal of Agricultural and Food Chemistry, 43, 1708-1711.

Liu, Z.L., Goh, S.H., \& Ho, S.H. (2007). Screening of Chinese medicinal herbs for bioactivity against Sitophilus zeamais Motschulsky and Tribolium castaneum (Herbst). Journal of Stored Products Research, 43, 290-296.

Lu, J. \& Wu, S. (2010). Bioactivity of essential oil from Ailanthus altissima bark against 4 major stored-grain insects. African Journal of Microbiology Research, 4(3), 154-157.

Luis, Â., Gil, N., Amaral, M.E., Domingues, F., \& Duarte, A.P. (2012). Ailanthus altissima (Miller) swingle: A source of bioactive compounds with antioxidant activity. Bioresources, 7, 2015-2020.

Mandal, S., Mitra, A., \& Mallick, N. (2008). Biochemical characterization of oxidative burst during interaction between Solanum lycopersicum and Fusarium oxysporum $f$. sp. lycopersici. Physiological and Molecular Plant Pathology, 72(1-3), 56-61.

Martens, S., Preuss, A., \& Matern, U. (2010). Multifunctional flavonoid dioxygenases: flavonol and anthocyanin biosynthesis in Arabidopsis thaliana L. Phytochemistry, 71(10), 1040-1049.

Milanović, S., Lazarević, J., Popović, Z., Miletić, Z., Kostić, M., Radulović, Z., Karadžić, D., \& Vuleta, A. (2014). Preference and performance of the larvae of Lymantria dispar (Lepidoptera: Lymantriidae) on three species of European oaks. European Journal of Entomology, 111(3), 371-378.

Miller, J.C. \& Hanson, P.E. (1994). Laboratory feeding tests on the development of $L$.dispar larvae with reference to plant taxa and allelochemicals. Agricultural Experiment Station Ir; Oregon State University. Agricultural Experiment Station, Oregon State University, Station Bulletin, 674, 1-63.

Okunade, A.L., Bikoff, R.E., Casper, S.J., Oksman, A., Goldberg, D.E., \& Lewis, W.H. (2003). Antiplasmodial activity of extracts and quassinoids isolated from seedlings of Ailanthus altissima (Simaroubaceae). Phytotherapy Research, 17, 675-677.

Onyilagha, J.C., Lazorko, J., Gruber, M.Y., Soroka, J.J., \& Erlandson, M.A. (2004). Effect of flavonoids on feeding preference and development of the crucifer pest Mamestra configurata Walker. Journal of Chemical Ecology, 30, 109-124.

Page, M., Sultana, N., Paszkiewicz, K., Florance, H., \& Smirnoff. N. (2012). The influence of ascorbate on anthocyanin accumulation during high light acclimation in Arabidopsis thaliana: further evidence for redox control of anthocyanin synthesis. Plant, Cell and Environment, 35, 388-404. 
Antifeeding and Insecticidal Activity of Ailanthus altissima and Morus alba

Pavela, R. (2011). Antifeedant activity of plant extracts on Leptinotarsa decemlineata Say. and Spodoptera littoralis Bois. Larvae. Industrial Crops Products, 32, 213-219.

Pavela, R., Zabka, M., Tylova, T., \& Kresinova, Z. (2014). Insecticidal activity of compounds from Ailanthus altissima against Spodoptera littoralis larvae. Pakistan Journal of Agricultural Sciences, 51, 101-112.

Pelletier, S. (1996). Alkaloids: chemical and biological perspectives, Volume 15, Pergamon, Oxford, UK.

Poljuha, D., Sladonja, B., Šola, I., Dudaš, S., Bilić, J., Rusak, G., Motlhatlego, K.E., \& Eloff, J.N. (2017). Phenolic composition of leaf extracts of Ailanthus altissima (Simaroubaceae) with antibacterial and antifungal activity equivalent to standard antibiotics. Natural Product Communications, 12, 1609-1612.

Polumackanycz, M., Sledzinski, T., Goyke, E., Wesolowski, M., \& Viapiana, A. (2019). A comparative study on the phenolic composition and biological activities of Morus alba L. commercial samples. Molecules, 24, 3082.

Popović, Z., Kostić, M., Stanković, S., Milanović, S., Sivčev, I., Kostić, I., \& Kljajić, P. (2013). Ecologically acceptable usage of derivatives of essential oil of sweet basil, Ocimum basilicum, as antifeedants against larvae of the gypsy moth, Lymantria dispar. Journal of Insect Science, 13(1), 1-12.

Pothinuch, P. \& Tongchitpakdee, S. (2019). Phenolic analysis for classification of mulberry (Morus spp.) leaves according to cultivar and leaf age. Journal of Food Quality, 2019, 2807690.

Przeor, M., Flaczyk, E., Kmiecik, D., Buchowski, M.S., Staniek, H., Tomczak-Graczyk, A., Kobus-Cisowska, J., Gramza-Michałowska, A., \& Foksowicz-Flaczyk, J. (2020). Functional properties and antioxidant activity of Morus alba L. leaves var. Zolwinska Wielkolistna (WML-P) - The effect of controlled conditioning process. Antioxidants, 9, 1-15.

Radojković, M.M., Zeković, Z.P., Vidović, S.S., Kočar, D.D., \& Mašković, P.Z. (2012). Free radical scavenging activity and total phenolic and flavonoid contents of mulberry (Morus spp. L., Moraceae) extracts. Hemijska Industrija, 66(4), 547-552.

Rahman, H.M.A., Rasool, M.F., \& Imran, I. (2019). Pharmacological studies pertaining to smooth muscle relaxant, platelet aggregation inhibitory and hyposensitive effects of Ailanthus altissima. Evidence-Based Complementary and Alternative Medicine, 2019:1871696.

Re, R., Pellegrini, N., Proteggente, A., Pannala, A., Yang, M., \& Rice-Evans, C. (1999). Antioxidant activity applying an improved ABTS radical cation decolorization assay. Free Radical Biology and Medicine, 26(9-10), 1231-1237.

Saha, A.K., Rahman, R., Shahriar, M., Saha, S.K., Al Azad, N., \& Das, D. (2013). Screening of six Ayurvedic medicinal plant extracts for antioxidant and cytotoxic activity. Journal of Pharmacognosy and Phytochemistry, 2, 181-188.

Rojht, H., Kosir, I.J., \& Trdan, S. (2012). Chemical analysis of three herbal extracts and observation of their activity against adults of Acanthoscelides obtectus and Leptinotarsa decemlineata using a video tracking system. Journal of Plant Diseases and Protection, 119, 59-67.

Sánchez-Salcedo, E.M., Mena, P., García-Viguera, C., Hernández, F., \& Martínez, J.J. (2015). (Poly)phenolic compounds and antioxidant activity of white (Morus alba) and black (Morus nigra) mulberry leaves: Their potential for new products rich in phytochemicals. Journal of Functional Foods, 18(B), 1039-1046.

Sanghi, S.B. \& Mushtaq, S. (2017). Pharmacological activity of Morus alba Linn. extracts - A review. Asian Journal of Pharmaceutical Education and Research, 6, 10-19.

Simmonds, M.S. (2003). Flavonoid-insect interactions: recent advances in our knowledge. Phytochemistry, 64, 21-30.

Simmonds, M.S.J. \& Stevenson, P.C. (2001). Effects of isoflavonoids from cicer on larvae of $H$. armigera. Journal of Chemical Ecology, 27, 965-977.

Singh, H., Cheema, H.K., \& Singh, R. (2020). Field evaluation of horticultural mineral oils and botanicals against bean thrips, Megalurothrips distalis (Karny) (Thysanoptera: Thripidae), in summer mung bean. Egyptian Journal of Biological Pest Control, 30, 1-8.

Singh, R., Bagachi, A., Semwal, A., Kaur, S., \& Bharadway, A. (2013). Traditional uses, phytochemistry and pharmacology of Morus alba Linn.: A review. Journal of Medicinal Plant Research, 7, 461-469. 
Stamp, N.E., Temple, M.P., Traugott, M.S., \& Wilkens, R.T. (1994). Temperature-allelochemical interactive effects on performance of Manduca sexta caterpillars. Entomologia Experimentalis et Applicata, 73, 199-210.

Šućur, J., Popović, A., Petrović, M., Anačkov, G., Malenčić, DJ., \& Prvulović, D. (2015). Allelopathic effects and insecticidal activity of Salvia sclarea L. Studia Universitatis Babes-Bolyai Chemia, 60(1), 253-264.

Tamura, S., Fukamiya, N., Okano, M., \& Koike, K. (2006). A new quassinoid, ailantinol H from Ailanthus altissima. Natural Product Research, 20, 1105-1109.

Tamura, S., Fukamiya, N., Okano, M., Koyama, J., Koike, K., Tokuda, H., Aoi, W., Takayasu, J., Kuchide, M., \& Nishino, H. (2003). Three new quassinoids, ailantinol E, F, and G, from Ailanthus altissima. Chemical and Pharmaceutical Bulletin, 51, 385-389.

Thaipitakwong, T., Numhom, S., \& Aramwit, P. (2018). Mulberry leaves and their potential effects against cardiometabolic risks: A review of chemical compositions, biological properties and clinical efficacy. Pharmaceutical Biology, 56, 109-118.

Treutter, D. (2006). Significance of flavonoids in plant resistance: A review. Environmental Chemistry Letters, 4, 147-157.

Tsao, R., Romanchuk, F.E., Peterson, C.J., \& Coats, J.R. (2002). Plant growth regulatory effects and insecticidal activity of the extracts of the tree of heaven (Ailanthus altissima L.). BMC Ecology, 2, 1-6.

Valeñtao, P., Fernandes, E., Carvalho, F., Andrade, P.B., Seabra, R.M., \& Bastos, M.L. (2002). Antioxidative properties of cardoon (Cynara cardunculus L.) infusion against superoxide radical, hydroxyl radical, and hypochlorous acid. Journal of Agricultural and Food Chemistry, 50, 4989-4993.

Vidović, M., Morina, F., Milić, S., \& Veljović Jovanović, S. (2015). An improved HPLC-DAD method for simultaneously measuring phenolics in the leaves of Tilia platyphyllos and Ailanthus altissima. Botanica Serbica, 39(2), 177-186.

Wagner, R.L. \& Card, J.A. (2020). Ailanthus altissima aqueous extract deters Spodoptera frugiperda oviposition. The Great Lakes Entomologist, 53(1), 68-72. 